\title{
Biodiversity of Gastropods in Intertidal Zone of Krakal Beach, Gunungkidul, Yogyakarta
}

\author{
G. A. B. Y. P. Cahyadi, Ragil Pinasti, Assyafiya Salwa, Maghfira Aulia Devi, Lutfiyah Rizqi Fajriana, \\ Nila Qudsiyati, Pinkan Calista, Rury Eprilurahman*
}

Faculty of Biology, Gadjah Mada University, Jl. Teknika Selatan, Sekip Utara, Yogyakarta, 55281, Indonesia

*Corresponding author:

E-mail: rurybiougm@ugm.ac.id

\begin{abstract}
Krakal Beach is located in Gunungkidul Regency, Yogyakarta Special Region. This beach is built by coral reefs. The coral reef is an ecosystem that can support various biota to live on it by being a habitat for many species, such as Molluscs. Mollusc is the phylum that has the most members after Arthropods. Approximately 60,000 living species and 15,000 fossil species belong to Mollusc. The phylum Mollusc is divided into seven classes, one of which is Gastropods. Gastropods are Molluscs that move with their abdominal muscles. Molluscs are so diverse, so this research is aimed to study the biodiversity of Molluscs in the intertidal zone of Krakal beach, Gunungkidul, Yogyakarta. The research was conducted on October 4th, 2019 at 03.10 WIB. The research held when ecological parameters were $\pm 21.3^{\circ} \mathrm{C}$ for water temperature, $\pm 3.6 \%$ for salinity, and 7.5 for $\mathrm{pH}$. The samples were collected using a purposive sampling method, preserved by using a dry preservation method, and identified by determining the morphological characteristics of the shell and referred to many references. This study found 7 families from the class Gastropod in the intertidal zone of Krakal beach, those are Aplustridae, Conidae, Cypraeidae, Mitridae, Muricidae, Nacellidae, and Turbinidae.
\end{abstract}

\section{Introduction}

Indonesia is an archipelagic country. As an archipelagic country, Indonesia's territory stretched from $6^{\circ} \mathrm{N}$ to $10^{\circ} \mathrm{S}$ and from $95^{\circ} \mathrm{E}$ to $142^{\circ} \mathrm{E}$, consists of 18,110 islands with $108,920 \mathrm{~km}$ coastline (Hutomo \& Moosa, 2005). Krakal Beach is located in Gunungkidul Regency, Yogyakarta Special Region. This beach is built by coral reefs. A coral reef is an ecosystem that can support various biota to live on it by being a habitat for many species, such as Molluscs (Bolam et al. 2002). Mollusc is the phylum that has the most members after Arthropods. Approximately 60,000 living species and 15,000 fossil species belong to Mollusc (Brusca \& Brusca, 1990). Molluscs are so diverse. They have conquered all habitats in the sea such as intertidal, littoral zone, even deep-sea hydrothermal vents. They also can be found in freshwater environments and land (Haszprunar \& Wanninger, 2012). Mollusc has diverse body shapes. Based on the body shape and the number of the shells, molluscs are classified into seven different classes: Aplacophora, Monoplacophora. Polyplacophora, Gastropods, Bivalves, Scaphopoda, and Cephalopod (Moore, 1960). Gastropods are Molluscs that move with their abdominal muscles (Houart, 2010). Also, biodiversity, abundance, and density of Molluscs in the intertidal zone can be used as a reference of the ecological quality in a certain area. This research aims to study the biodiversity of Molluscs in the intertidal zone of Krakal beach, Gunungkidul, Yogyakarta. Yogyakarta.

\section{How to cite:}

Cahyadi, G. A. B. Y. P., Pinasti, R., \& Salwa, A et al. (2021). Biodiversity of gastropods in intertidal zone of Krakal Beach, Gunungkidul, Yogyakarta. 1st Bioinformatics and Biodiversity Conference. NST Proceedings. pages 16-24. doi: 


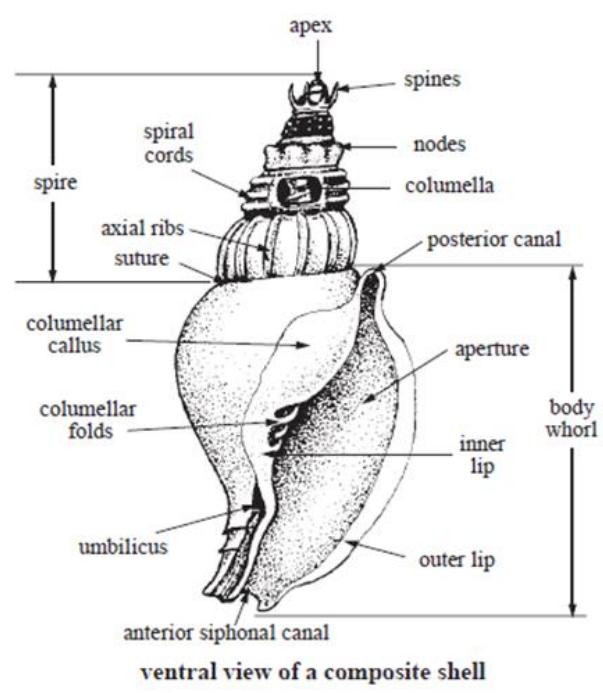

Figure 1. Morphology Shell of Gastropods (Carpenter \& Niem, 1998)

\section{Material and Methods \\ Study area}

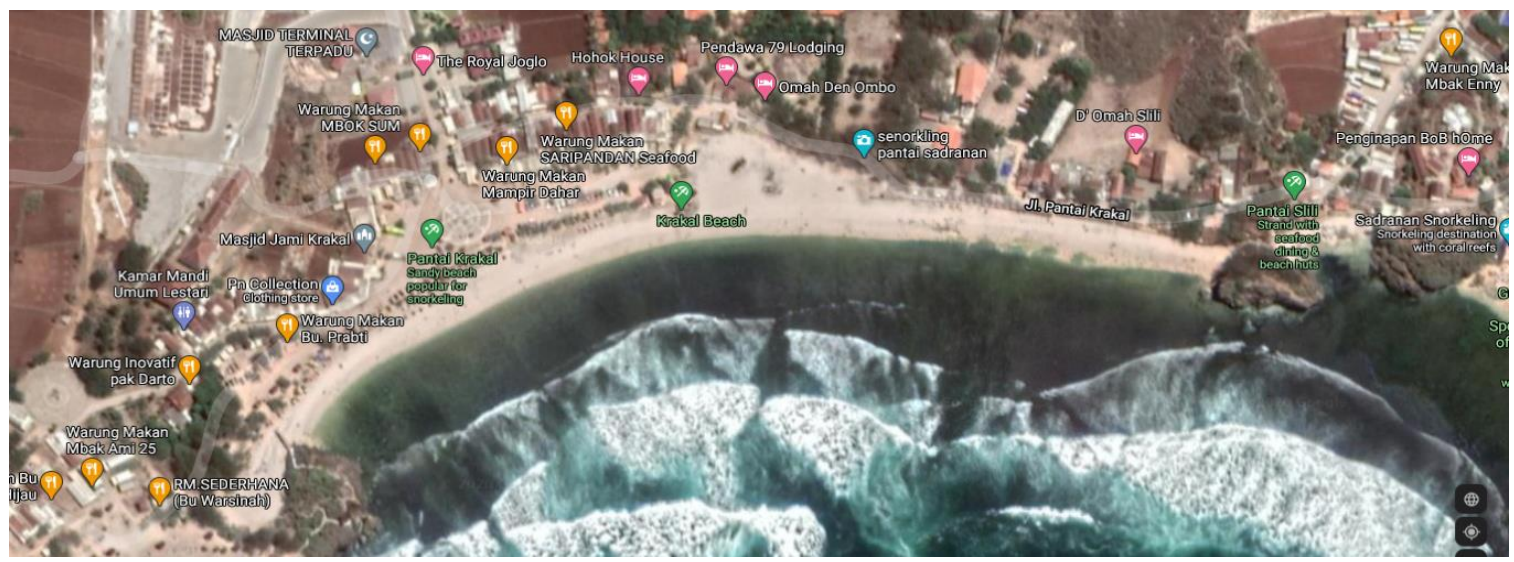

Figure 2. Research Site in Krakal Beach (Source: Google Maps)

\section{Materials and tools}

The materials used in this research were gastropod samples, seawater, aquadest, and a liquid detergent. The sampling was done by using a quadratic plot $(1 \mathrm{~m} \times 1 \mathrm{~m})$ because the result of this research was also used to determine gastropod abundance. The tools used for this research were ziplock plastics, tweezers, brushes, portable stove, aluminum pot, laminated millimeter blocks, paper labels, thermometer, ruler, indicator universal, and digital camera.

\section{Method}

The study area was divided into 13 transect lines, with 5 meters distance for each transect. The transect was placed perpendicular to the shoreline and each transect is divided into 4 squares (forming a quadrat plot) with $1 \mathrm{~m} \times 1 \mathrm{~m}$ area. The number of plots is based on the length of the coastline, the coast's intertidal state, and the condition of the tide. Gastropods species found in the quadrat plots were taken and recorded. After sample collection, gastropods were documented using a digital camera, on top of a laminated millimeter block. The length of the shell was measured by a ruler. Then, samples were preserved by using the dry preservation method. The steps of the 
dry preservation method are gastropods were boiled to separate the visceral mass from the shell and then the shells were cleaned by using a brush.

\section{Results and Discussion}

\section{Results}

Table 1. Environmental parameters in Krakal Beach

\begin{tabular}{lc}
\hline Parameters & Value \\
\hline Water's Temperature & $21.3^{0} \mathrm{C}$ \\
Salinity & $36 \%$ \\
$\mathrm{Ph}$ & 7.5 \\
\hline
\end{tabular}

The environmental parameters in the Krakal Beach based on a survey in 2019 have water's temperature $21.33^{\circ} \mathrm{C}$, salinity was $36 \%$ and $\mathrm{pH}$ was 7.5 , and $\mathrm{pH}$ was 8 .

Table 2. Biodiversity of gastropods in Krakal Beach

\begin{tabular}{|c|c|c|}
\hline No & Family & Species \\
\hline \multirow[t]{2}{*}{1} & Aplustridae & Aplustrum amplustre \\
\hline & & Hydatina physis \\
\hline \multirow[t]{3}{*}{2} & Conidae & Conus diadema \\
\hline & & Conus coronatus \\
\hline & & Conus distans \\
\hline \multirow[t]{2}{*}{3} & Cypraeidae & Monetaria moneta \\
\hline & & Monetaria annulus \\
\hline \multirow[t]{3}{*}{4} & Mitridae & Strigatella litterata \\
\hline & & Strigatella paupercula \\
\hline & & Strigatella retusa \\
\hline \multirow[t]{3}{*}{5} & Muricidae & Morula uva \\
\hline & & Tylothais virgata \\
\hline & & Tenguella marginalba \\
\hline 6 & Nacellidae & Cellana sp. \\
\hline 7 & Turbinidae & Turbo bruneus \\
\hline
\end{tabular}


Table 2 shows the diversity of classes of gastropods that are found in Krakal Beach. There are 15 species from 7 families of classes Gastropods that are found in Krakal Beach, those are Aplustridae, Conidae, Cypraeidae, Mitridae, Muricidae, Nacellidae, Turbinidae.

\section{Discussion}

Turbinidae is a top-shaped snail, with a thick shell and turbinate to conical in shape. It has a spiral to nodular outer sculpture. The aperture is rounded without a siphonal canal. Turbinidae has a strongly calcified operculum in the external part with a smooth inner lip. la This family mainly lives in shallow waters of warm temperate and tropical, especially on the rocky shore and coral reef. Most species of this family are vegetarians, feeding on small epibenthic algae and detritus of vegetables. The distribution of Turbinidae is commonly in the Indo-West Pacific shore (Carpenter \& Niem, 1998; Abbot \& Dance, 2000).
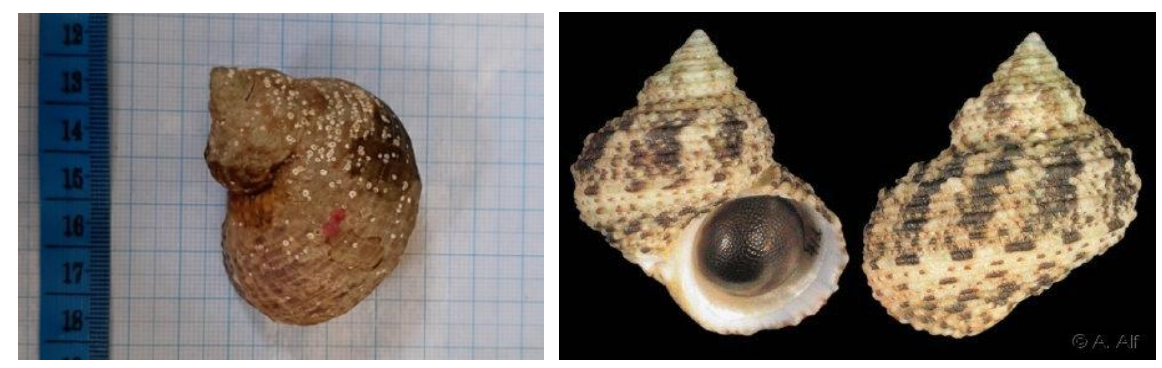

Figure 3. Family of turbinidae; Turbo bruneus

Family Conidae (cone snails) are renowned for their often dazzling shell coloration patterns and venomous feeding habits (Hendricks, 2018). The conidae, Conus species are in shallow water and abundance in two major geographic distribution patterns (Khon, 2001). Conidae can be found in tropical and subtropical seas, so the adaptation rate is high (Tyron, 1884). The suitable ecological parameters for this family are $-1.82{ }^{\circ} \mathrm{C}-28.86^{\circ} \mathrm{C}$ for water temperature and $23.803-38.444$ PSU for water salinity according to Parr (2014).
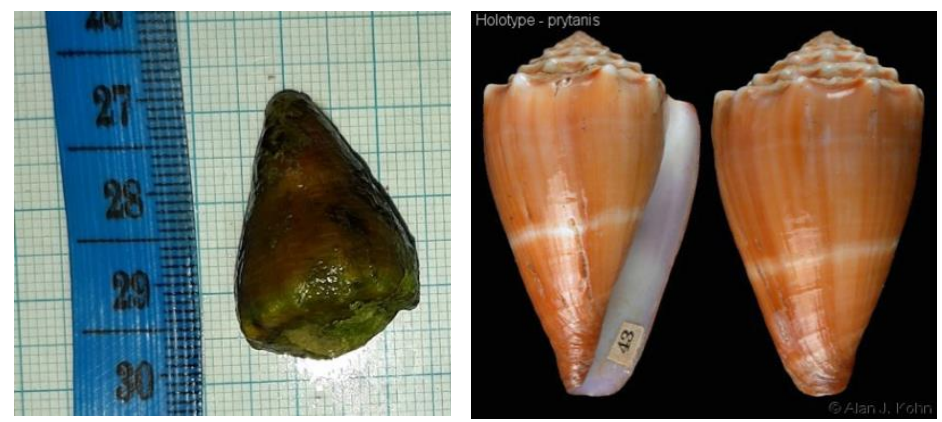

(a)
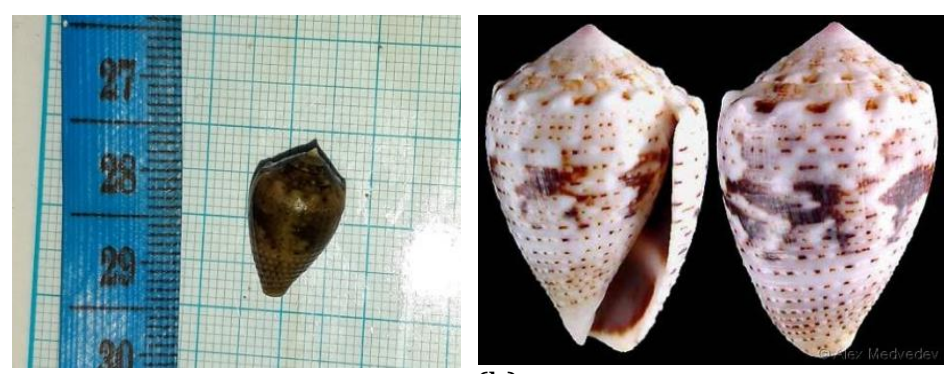

(b) 

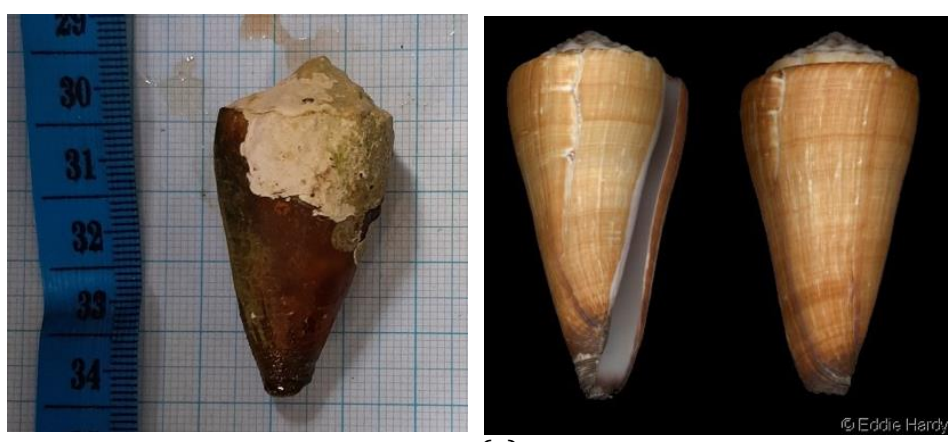

(c)

Figure 4. Family of Conidae; (a) Conus diadema, (b) Conus coronatus, (c) Conus distans

The Muricidae is commonly known as murex or rock whelks. Most of these family member are predatory snail (Benkendorf et al., 2015). It has radula and carnivorous. The Muricidae shell has a higher spire. The shell sculpture featured spines, nodules, horns, and lamellae. The aperture is small and round with a narrow columellar lip (Leal, 2003). Muricidae is varying in size from the small insignificant rock shells $(12 \mathrm{~mm})$ to the large horny Chicoreus ramosus $(300 \mathrm{~mm})$. Muricidae family lives in the intertidal zone to the ocean depths of tropical and subtropical oceans. Muricidae's presence is related to its ability of the species to adapt to the environment and flexibility in determining its prey (Poutiers, 1998). The suitable ecological parameters for this family are 2.028 of $-28.918^{\circ} \mathrm{C}$ for water temperature and $27.165-38.444$ PSU for water salinity according to Parr (2014).
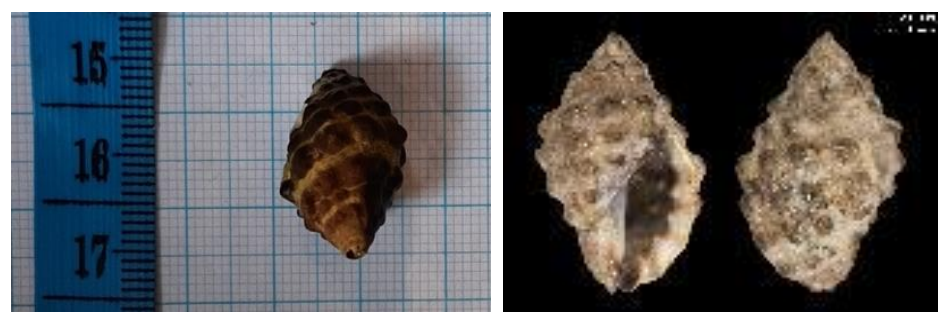

(a)
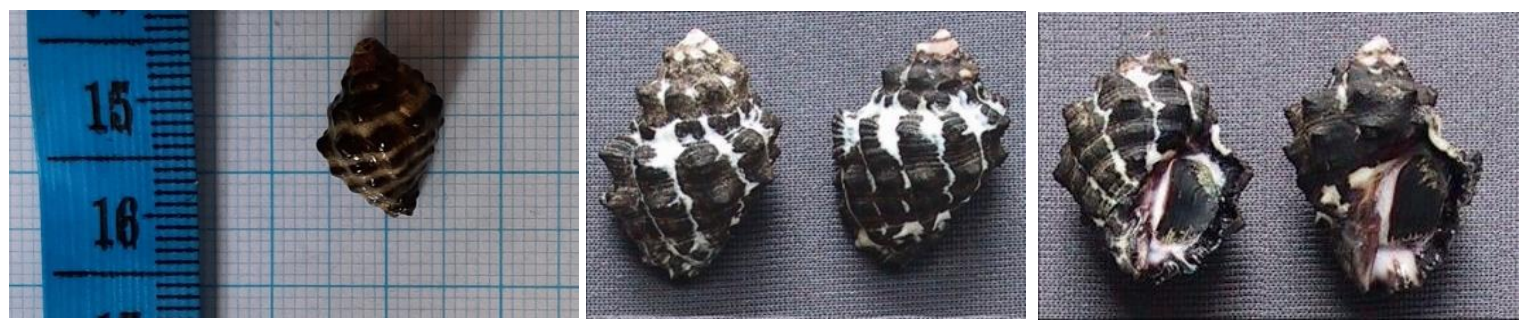

(b)
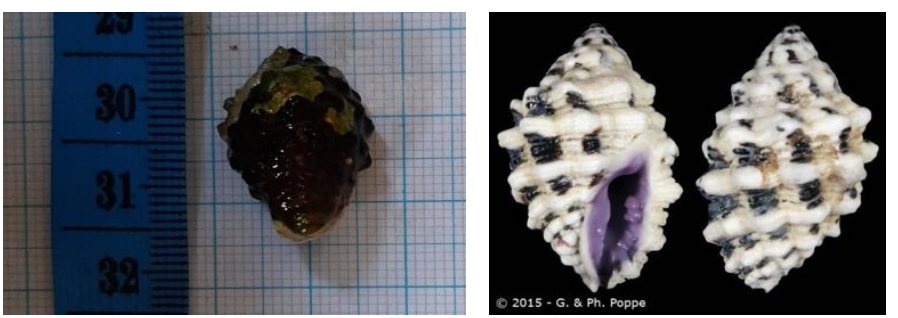

(c)

Figure 5. Family of Muricidae; (a) Tenguella marginalba, (b) Tylothais virgata, (c) Morula uva 
Mitridae family has key features: solid, usually fusiform, and colorful shell, The shell has columellar folds, smooth inner side labrum, and predominant spiral sculpture (Fedosov et al., 2018). Most Mitridae species inhabit tropical seas. Mitridae has a high diversity Indo-Pacific region because Mitridae species mostly live in the Indo-Pacific region (Rosenberg \& Resh, 1993). The suitable ecological parameters for this family are 9.381 of $-28.409^{\circ} \mathrm{C}$ for water temperature according to Parr (2014).
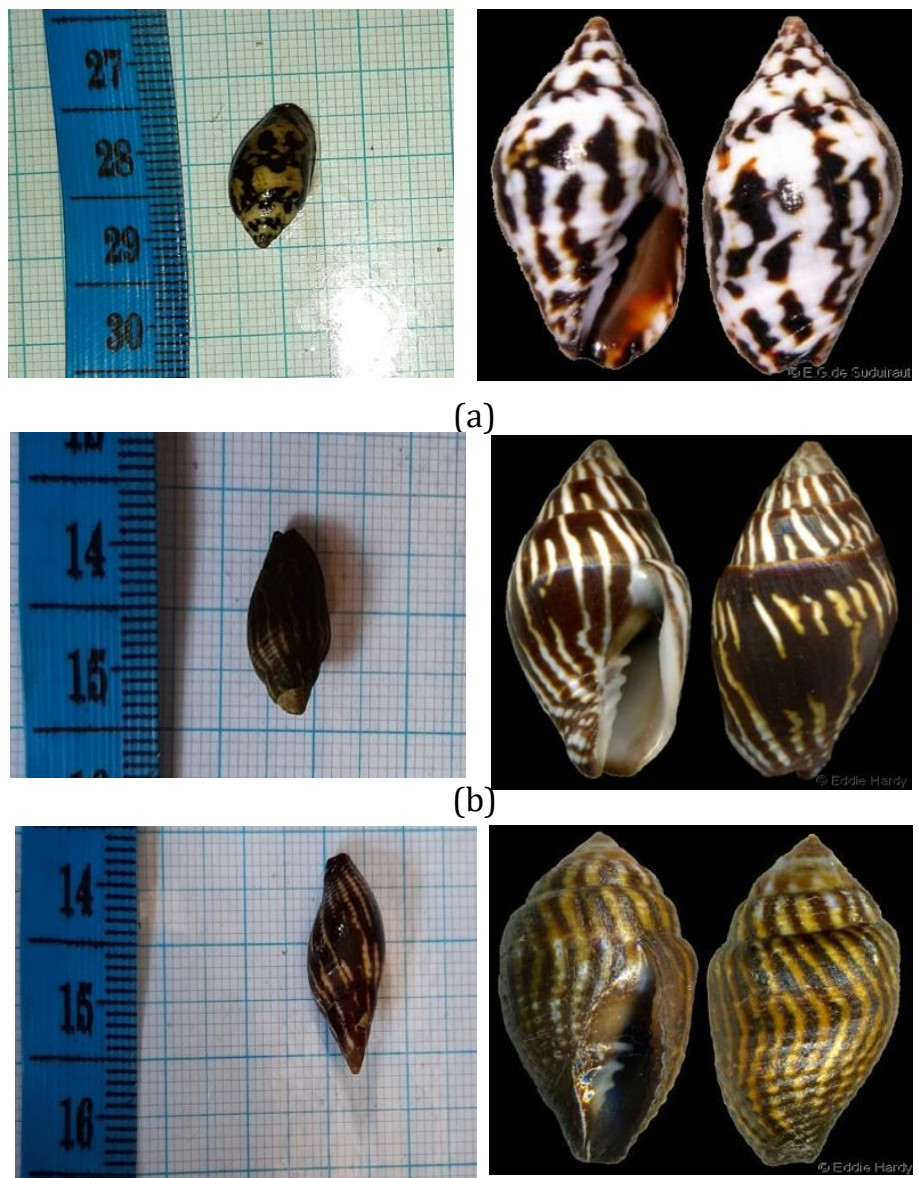

(c)

Figure 6. Family of Mitridae; (a) Strigatella litterata, (b) Strigatella paupercula, (c) Strigatella retusa

The aperture of Cypraeidae are spaced and usually toothed. The surface shells of Cypraeidae are colorful, shiny, and smooth. Their mantles are often as colorful as their shells. Cypraeidae are omnivorous. Cypraeidae live in the warm sea. Cypraeidae are not toxic animals. Sometimes, the mantle fully expands, may camouflage the shell itself from predators. The family Cypraeidae is distributed in the tropical and subtropical seas. Many species are generally found in tropical shallow-water reefs and can adapt to temperate waters and/or deepwater environments. Most species are herbivorous grazers, but some are carnivorous, being more commonly eaten sponge. (Passamonti, 2015). The suitable ecological parameters for this family are 6.819 of $-28.84{ }^{\circ} \mathrm{C}$ for water temperature and 33.473 - 38.201 PSU for water salinity according to Parr (2014). 

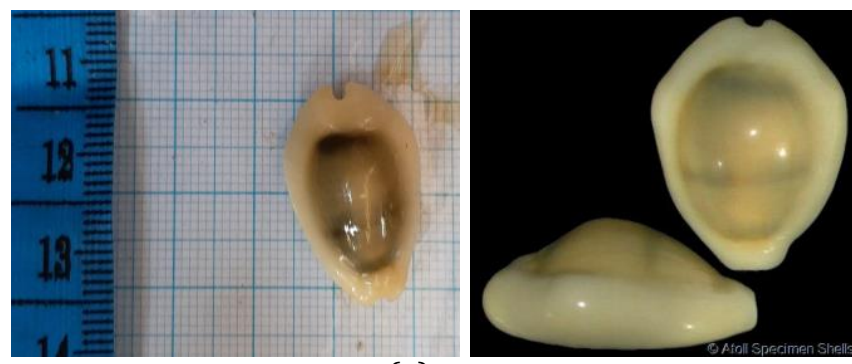

(a)
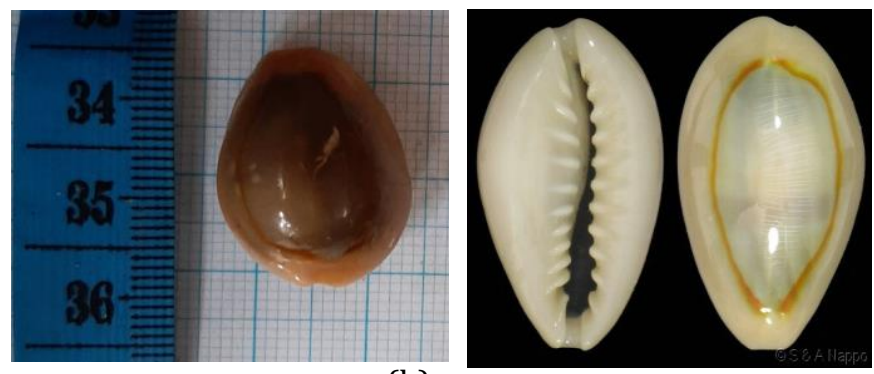

(b)

Figure 7. Family of Cypraeidae; (a) Monetaria moneta, (b) Monetaria annulus

The Aplustridae is a taxonomic family of sea snails or bubble snails, marine gastropod molluscs in the superfamily Acteonoidea that comprising about a dozen valid species found in the tropics worldwide (Bouchet et al., 2005; Tan et al., 2014). The soft parts of animals in this family are brightly colored. The oval bubble-shaped shell is thin and fragile and has a sunken spire. The shell is white or beige-colored with colored bands or stripes. Aplustridae has no operculum and has a large aperture. The soft parts of the animal cannot retract completely into the shell, and therefore these animals depend for their defense on swimming and camouflage. All species are predators that appear to feed exclusively on cirratulid polychaete worms, which are swallowed whole (Tan et al., 2014; Doring, 2020). Aplustridae can be found in-depth 0-20 m, within temperature 13-14 ${ }^{\circ} \mathrm{C}$, and salinity 34-35 PSU (Bouchet et al., 2005; Burn, 2006).
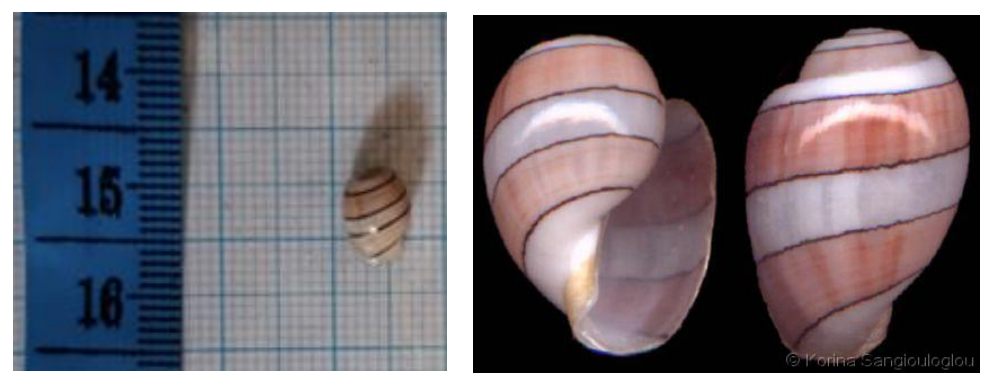

(a)
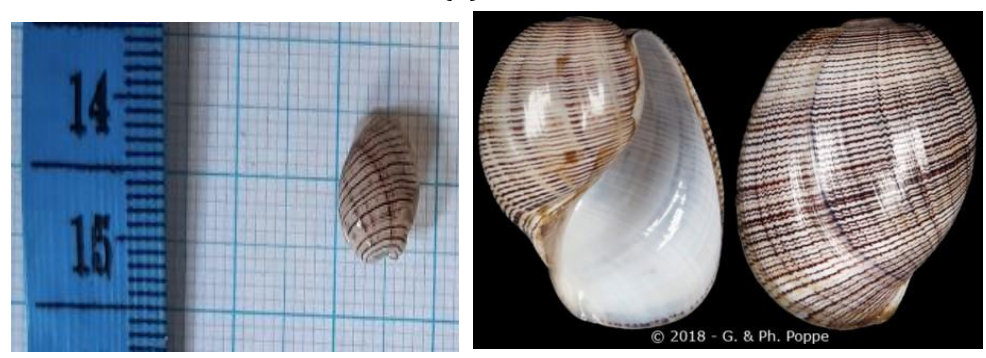

(b)

Figure 8. Family of asplustridae; (a) Aplustrum amplustre, (b) Hydatina physis 
Nacellidae is a taxonomic family of sea snails or true limpets, marine gastropod molluscs from ordo Patellogastropoda. The species of the genus Nacella (family Nacellidae; with subgenera Nacella and Patinigera) are distributed in Antarctic and Subantarctic waters. The shell morphology is typically elliptical, high-arched, with the apex strongly curved forward and downward, sometimes almost at the anterior end. The surface of the shell varies from very smooth (e.g. N. mytilina) to strongly radially ridged (e.g. N. magellanica). The external shell color is pale-olive to brownish, the apex coppery; the inside is silvery iridescent to reddish-bronze. These snails prefer to live on low intertidal and subtidal rocky shores between 0-20 m. This order grazes on algae that grow on rocks (Golikov \& Starobogatov, 1975; Gonzales-Wevar et al., 2018).

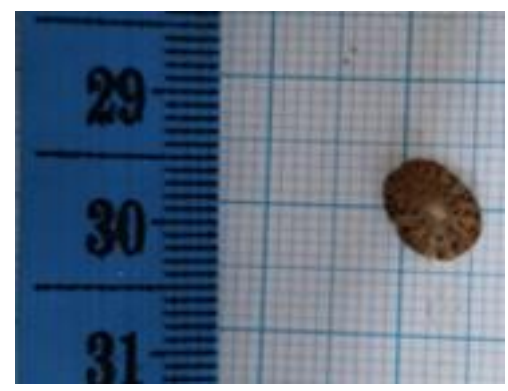

\section{Conclusion}

Figure 9. Family of Nacellidae; Cellana sp.

There are seven families of Gastropods found in Krakal Beach. Conidae, Muricidae, and Mitridae are the family with the highest diversity with three species found. This is because Krakal Beach is close to the ideal place for those families to live in with the ecological parameters.

\section{Acknowledgment}

We would like to say thanks to Kelompok Studi Kelautan, Faculty of Biology, Universitas Gadjah Mada, including its members, especially from the Division of Mollusca for helping us in finishing this research and paper. We also say thank you to Drs. Trijoko, M. Si. as the advisor of Kelompok Studi Kelautan, and Rury Eprilurahman, S. Si. M. Sc. as research supervisor.

\section{References}

Abbot, R. T., \& Dance, S. P. (2000). Compendium of seashells. A full-colour guide to more than 4,200 of the world's marine shells. Hong Kong: Odyssey Pub. 83, 189

Benkendorff, K., Rudd, D., Nongmaithem, B. D., Liu, L., Young, F., Edwards, V., Avila, C., \& Abbott, C. A. (2015). Are the traditional medical uses of Muricidae molluscs substantiated by their pharmacological properties and bioactive compounds?. Marine Drugs, 13(8), 5237-5275.

Bolam, S. G., Fernandes, T. F., \& Huxham, M. (2002). Diversity, biomass, and ecosystem processing in the marine benthos. Ecological monographs, 72(4).

Bouchet, P., Rocroi, J. P., Frýda, J., Hausdorf, B., Ponder, W., Valdes, A., \& Warén, A. (2005). A nomenclator and classification of gastropod family-group names. Malacologia, 47(1-2), 1-368.

Brusca, R. C. \& G. J. Brusca. (1990). Invertebrates. Systematic Zoology, 40(2), 245-247.

Burn, R. (2006). A checklist and bibliography of the Opisthobranchia (Mollusca: Gastropoda) of Victoria and the Bass Strait area, southeastern Australia. Museum Victoria Science Reports, 10(142), 1-42.

Carpenter, K. E., \& Niem, V. H. (1998). The living marine resources of the western Central Pacific: 1. Seaweeds, corals, bivalves and gastropods. Rome: Food and Agriculture Organization of the United Nations, 1.

Döring, M. (2020). English Wikipedia - Species Pages. Wikimedia Foundation. doi:10.15468/c3kkgh

Fedosov, A., Puillandre, N., Herrmann, M., Kantor, Y. (2018). The collapse of Mitra: molecular systematics and morphology of the Mitridae (Gastropoda: Neogastropoda). Zoological Journal of the Linnean Society, 183(2), 253-337.

Golikov, A. N., \& Y.I, Starobogatov. (1975). Systematics of prosobranch gastropods. Malacologia 15(2), $185-232$. 
González-Wevar, C. A., Hüne, M., Rosenfeld, S., Nakano, T., Saucède, T., Spencer, H., \& Poulin, E. (2018). Systematic revision of Nacella (Patellogastropoda: Nacellidae) based on a complete phylogeny of the genus, with the description of a new species from the southern tip of South America. Zoological Journal of the Linnean Society, XX, 303-336.

Haszprunar, G. \& A. Wanninger. (2012). Molluscs. Current Biology, 22(13), R510-R514.

Hendricks, J. (2018). Diversity and preserved shell coloration patterns of Miocene Conidae (Neogastropoda) from an exposure of the Gatun Formation, Colón Province, Panama. Journal of Paleontology, 92(5), 804-837.

Hutomo, M. \& M. K. Moosa. (2005). Indonesian marine and coastal biodiversity: Present status. Indian Journal of Marine Species, 34(1), 88-97.

Kohn, A. J. (2001). The conidae of India revisited. Phuket Marine Biological Center Special Publication, 25(2), 357-362.

Leal, J.H. (2003). Gastropods. Volume 1: Introduction, molluscs, crustaceans, hagfishes, sharks, batoid fishes, and chimaeras. FAO Species Identification Guide for Fishery Purposes and American Society of Ichthyologists and Herpetologists Special Publication, 5(1), 99-147.

Moore, R. C. (1960). Mollusca 1. Treatise on invertebrate paleontology. Geological Society of America, New York.

Passamonti, M. (2015). The family Cypraeidae (Gastropoda Cypraeoidea) an unexpected case of neglected animals. Biodiversity Journal, 6(1), 449-466.

Parr, C. S., Wilson, N., Leary, P., Schulz, K. S., Lans, K., Walley, L., Hammock, A., Goddard, A., Rice, J., Studer, M., Holmes, J. T., \& R.J. Corrigan, Jr. (2014). The encyclopedia of life v2: providing global access to knowledge about life on earth. Biodiversity data journal, (2), e1079, doi:10.3897/BDJ.2.e1079.

Poutiers, J. M. (1998). Bivalves (Acephala, Lamellibranchia, Pelecypoda). Carpenter, KE and VH Niem, The Living Marine Resources of the Western Central Pacific. Volume 1: Seaweeds, corals, bivalves and gastropods. FAO Species Identification Guide for Fishery Purposes. Rome: Food and Agriculture Organization of the United Nations.

Rosenberg, D. M. (1993). Freshwater biomonitoring and Benthic Macroinvertebrates. New York: Chapman and Hall.

Tan, S. K., Low, M. E., Nguang, L. H., \& Toh, C. H. (2014). Singapore Mollusca: 8. The family Aplustridae (Gastropoda: Heterobranchia: Acteonoidea). Nature in Singapore, 7, 121-127.

Tryon, G. W. (1884). Manual of Conchology, structural and systematic: with illustrations of the species (Vol. 6). Philadelphia: Academy of Natural Sciences. 